\title{
肥育豚へのパン屑利用低リジン飼料給与による 筋内脂肪含量の増加
}

\author{
家入誠二・崎村武司・石橋 誠* ・勝俣昌也** ・梶 雄次 ${ }^{* * *}$ \\ 熊本県農業研究センター, 熊本県合志市栄 3801，861-1113 \\ * 熊本県阿蘇農業改良普及指導課, 熊本県阿蘇市宮地 2402, 869-2612 \\ ** (独)農業・食品産業技術総合研究機構, 畜産草地研究所, つくば市池の台 2, 305-0901 \\ *** (独)農業・食品産業技術総合研究機構, 九州沖縄農業研究セン夕ー, \\ 熊本県合志市須屋 2421，861-1192
}

(2006 年 5 月 19 日受付, 2006 年 8 月 2 日受理)

\begin{abstract}
要 約 現在, 食品残さは重要な飼料資源と認識されており, 食品残さを給与して肉質 を改善する研究が, 多くの研究機関で実施されている。近年, 食品残さであるパン屑を肥 育豚飼料へ添加することによって, 豚の胸最長筋における筋内脂肪含量（IMF）が増加す ることが報告されているが，その作用機作については検討されていない。飼料にパン屑を 添加した場合, その原料である小麦のアミノ酸組成を反映し, 結果的に, いくつかのアミ ノ酸が要求量を満たさなくなると予想される。そして, そのことが IMF 増加の一因だと推 察された。そこで, パン屑を添加した飼料におけるアミノ酸濃度と IMF との関係について 検討した。トウモロコシとダイズ粕を主原料とする対照飼料に対して, パン屑を添加した パン屑添加飼料 (BS 飼料; 日本飼養標準によるリジン要求量に対して充足率約 $70 \%$ ), パ ン屑添加飼料では不足するアミノ酸（リジン，メチオニン，トレオニンおよびトリプト ファン) を添加したパン屑十アミノ酸添加飼料 (BS+ AA 飼料) を調整した。飼養試験に はランドレース種去勢豚と雌豚合計 24 頭を供試した。それぞれの飼料に去勢雄 4 頭, 雌 4 頭を配置し, 体重 $40 \mathrm{~kg}$ から $110 \mathrm{~kg}$ まで各飼料を不断給餌した。飼養試験終了後と畜し, 枝肉の品質を調査するとともに，胸最長筋の IMF 含量を調査した。その結果，BS 飼料の 給与は背脂肪厚に明確な影響を及ぼさなかった。一方， BS 飼料を給与した豚の胸最長筋 の IMF 含量は他の 2 区に比較して高くなった（BS 区と BS+AA 区間 ; P $<0.05$, BS 区と 対照区間 ; $\mathrm{P}=0.0515$, 対照区 $2.29 \%, \mathrm{BS}+\mathrm{AA}$ 区 $1.98 \%$ に対し, BS 区 $3.52 \%) 。 \mathrm{BS}+\mathrm{AA}$ 飼料を給与した肥育豚の 1 日平均増体重, 飼料摂取量, 飼料要求率, 背脂肪厚およびわき 腹の脂肪厚は対照飼料を給与した肥育豚のそれらと同等であった。以上の結果は，これま で報告されてきたパン屑添加飼料を給与した肥育豚における胸最長筋の IMF 含量増加が, パン屑添加に伴う一部のアミノ酸含量の低下に由来することを示唆している。
\end{abstract}

Enhancement of Intramuscular Fat Content in Longissimus Dorsi Muscle of Finishing Pigs Fed a Low Lysine Diet Including Bread Crumbs

S. Ieiri, T. Sakimura, M. Isibasi*, M. Katsumata** and Y. KaJi***

Kumamoto Agricultural Research Center, Sakae 3801, Koshi-shi, Kumamoto, 861-1113, Japan * Kumamoto Prefectural Government, Aso Extension Division, Miyaji 2402, Aso-shi, Kumamoto, 869-2612, Japan

** National Institute of Livestock and Grassland Science, Ikenodai 2, Tsukuba, 305-0901, Japan

*** National Agricultural Research Center for Kyushu Okinawa Region, Suya 2421, Koshi-shi, Kumamoto, 861-1192, Japan

連絡者 : 家入誠二（E-mail : ieiri-s-dz@pref.kumamoto.lg.jp Tel. 096-248-6433） 


\section{緒言}

豚の育種改良, 飼養技術開発は, 脂肪蓄積量の 少ない豚肉を，低価格で安定的に供給することを 目的に行われてきた。しかし，平成 12 年度は 65 万トンであった豚肉の輸入量は, 平成 16 年度に は 86 万トンまで増えている。一方で, 国内の豚の 之畜頭数は漸減傾向にあり, 輸入豚肉之の差別化 を図りたい養豚生産者は, 高品質なテーブルミー 卜生産に期待を寄せている。また，2004 年 3 月に 新たに閣議決定された食料・農業・農村基本計画 においても, 食糧自給率の向上之経営の安定化, 生産物の輸出を屯視野に入れた攻めの農業への転 換が明記されており, 養豚においても, 海外生産 豚肉之明確に差別化できる高品質豚肉生産技術の 開発が望まれている。

このような背景の中, 銘柄豚やブランド豚と呼 ばれる「肉質重視」の豚肉が, 各地で生産される ようになり,「TOKYO-X」や「霜降りレッド」等 の, 豚肉に脂肪交雑が入る系統豚の開発が盛んに なっている。しかし，これらの系統豚の開発には 6〜 7 年の長期選抜が必用であり, 養豚生産基盤が 小さい地域では, 改良事業に取り組むことが難し い状況となっている。栄養制御によって高品質豚 肉を生産できれば，生産基盤が小さい地域におい ても高品質豚肉の生産が可能になると期待でき る。

パンを主体とする食品リサイクル飼料を給与す ると, 筋内脂肪含量 (Intramuscular fat; IMF) の高い豚肉を生産することができると, すでに 2002 年に入江が総説の中で言及している1)。そし て，栄養制御によって IMF を高く出来ることを， 国内で科学的に最初に示したのは，パン屑給与に よる岩本らの報告 ${ }^{2}$ である。

この問題に対し， 2 通りの仮説が考えられる。 日本標準飼料成分表 $(2001)^{3)}$ によると，パン屑の 粗脂肪含量は $4.7 \%$ ，卜ウモロコシは $3.8 \%$ で，約 $20 \%$ パン屑のほうが粗脂肪含量が高い。五訂食品 成分表 $(2002)^{4)}$ によると, 乾燥したパン粉の脂質 含量は $6.8 \%$ と,さらに高くなる。したがって, パ ン屑を給与すると，豚の粗脂肪摂取量が高くなる と思われる。つまり, 粗脂肪摂取量が高いために,
IMF 屯高くなるという仮説が，1つめの仮説であ る。一方，アミノ酸含量に原因を求めるのが $2 つ$ めの仮説である。言うまでもなく，パン屑の原料 は小麦などの穀物が主であり, そのアミノ酸組成 はトウモロコシと同等である ${ }^{3)}$ 。岩本ら (2005) の 報告 ${ }^{2}$ のように，市販配合飼料をパン屑で代替す ると, リジンをはじめとするいくつかのアミノ酸 が, 日本飼養標準・豚 $(2005)^{5)}$ が推奨する要求量 を満たさなくなる。パン屑給与による IMF 増加 の主たる原因を，このようなアミノ酸不足に求め るのが 2 つめ仮説である。

KATSUMATA ら $(2005)^{6)}$ は, トゥモロコシとダイ ズ粕を主体とする飼料中リジン濃度の充足率を, 要求量の $70 \%$ にまで低くすることによって, 胸 最長筋中の IMF を対照区の 2 倍程度にまで高く できることを示した。この実験結果は, 上述した 第 2 の仮説，すなわち，パン屑給与によるアミ， 酸不足が IMF 増加の主たる原因であるという仮 説を支持する結果になっている。しかし，パン屑 を配合した飼料に，そのままでは不足するアミ， 酸を加え, IMFに及ぼす影響を検討した例は無 く, パン屑を配合した場合の飼料中のアミノ酸濃 度と IMF の関係は，未だ検証されていない。

以上の背景から，パン屑を肥育豚用飼料に用い ることによって生じるいくつかのアミノ酸の不足

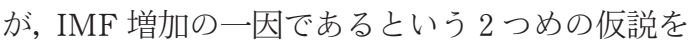
検証することを, 本研究の目的としている。具体 的には，パン屑給与によって不足するアミノ酸 を, 飼料用アミノ酸を添加することによって補 い, パン屑単独の効果と比較した。また, 地域に 存在する未利用資源を食品リサイクル飼料として 有効活用する目的で，パン屑に加えてトウフ粕を 飼料原料として使用した。

\section{材料および方法}

日本標準飼料成分表 $(2001)^{3)}$ によるパン屑とト ウフ粕の一般成分, 可消化エネルギー（DE）およ び主なアミノ酸含量を表 1 に示した。比較のた め, トゥモロコシとダイズ粕の成分を同時に示し た。トウモロコシに比較して, パン屑は繊維含有 量が少なく，可消化エネルギー（DE）と粗タンパ ク質 (CP) の濃度が高い。一方, ダイズ粕に比較 
表 1. 大豆粕, トゥフ粕, トゥモロコシならびにパン屑の一般成分とアミノ酸含量

\begin{tabular}{|c|c|c|c|c|}
\hline 成 分 & 大豆粕 & トウフ粕 & トウモロコシ & パン屑 \\
\hline \multicolumn{5}{|l|}{ 一般成分（\%） } \\
\hline 水分 & 11.7 & 4.3 & 13.5 & 9.5 \\
\hline 粗タンパク質（CP） & 46.1 & 25.5 & 8.8 & 14.7 \\
\hline 粗脂肪 & 1.3 & 14.0 & 3.9 & 3.8 \\
\hline NFE & 29.4 & 37.1 & 70.7 & 69.1 \\
\hline 粗繊維 & 5.6 & 15.3 & 1.9 & 0.3 \\
\hline 租灰分 & 5.9 & 3.8 & 1.2 & 2.6 \\
\hline 可消化エネルギー（Mcal/kg） & 3.13 & 2.93 & 3.57 & 3.93 \\
\hline \multicolumn{5}{|l|}{ アミノ酸（\%） } \\
\hline アルギニン & 3.36 & 1.47 & 0.41 & 0.42 \\
\hline ヒスチジン & 1.19 & 0.63 & 0.24 & 0.28 \\
\hline イソロイシン & 2.05 & 0.98 & 0.31 & 0.47 \\
\hline ロイシン & 3.38 & 1.82 & 1.06 & 0.91 \\
\hline リジン & 2.91 & 1.42 & 0.24 & 0.20 \\
\hline メチオニン & 0.52 & 0.41 & 0.15 & 0.20 \\
\hline トレオニン & 1.74 & 0.96 & 0.30 & 0.37 \\
\hline トリプトファン & 0.64 & 0.32 & 0.10 & 0.12 \\
\hline バリン & 2.07 & 1.14 & 0.43 & 0.54 \\
\hline
\end{tabular}

パン屑とトゥフ粕は日本標準飼料成分表（2001 年版）より。その他は分析值。

して,トゥフ粕は粗脂肪含有量が高く, アミノ酸, 特にリジンの含量が低いことがわかる。

表 2 に, 給与した飼料の配合設計と成分值を示 した。トウモロコシとダイズ粕を主原料とする対 照区，パン屑とトゥフ粕を飼料に配合した BS 区, BS 区の飼料にリジン, メチオニン，トレオニ ンおよびトリプトファンを添加した BS+AA 区 の 3 区を設定した。パン屑とトウフ粕の給与に よって, BS 区のリジン濃度は, 日本飼養標準・ 豚 $(2005)^{5)}$ が推奨する要求量よりあ $25 \%$ 程度低 くなっている。さらに，40-70 kg 用の飼料では, その他のアミノ酸も要求量を若干下回るように設 計されている。一方, BS+ AA 区は, 表 2 で示し たすべてのアミノ酸が要求量を満たすように，ア ミノ酸を添加している。パン屑ならびにトウフ粕 給与によるアミノ酸不足が IMF 増加の一因だと すれば，BS 区で高くなる IMF は，BS+AA 区で は対照区と同様の值にまで低くなることが期待さ れる。
飼養試験は, 平成 15 年 6 月から 9 月まで, 熊本 県農研センターにおいて実施された。供試豚はラ ンドレース種 24 頭で, 去勢雄, 此脽豚各 4 頭を各区 にそれぞれ配置した。また, 群飼により体重 40 $\mathrm{kg}$ から $110 \mathrm{~kg}$ まで表 2 の飼料を不断給与した。 期間中に，関節炎によって起立不能となった，BS 区と BS+ AA 区各 1 頭の試験豚を除き, 1 日増体 量, 飼料摂取量を測定するとともに, 肥育終了後, 熊本県畜産流通センターにてと畜解体し, 背脂肪 厚を調査した。なお, と畜は, 成長速度の違いに よって, 2 回に分け実施し, 熊本県畜産流通セン ターにおいて採取した最後胸椎と第 1 腰椎間の胸 最長筋（ロース）のIMFをエーテル抽出法 ${ }^{6}$ に て, 調査した。給水は自由飲水とした。

統計処理は $\mathrm{HARVEY}^{7)}$ の最小 2 乗法分散分析プ ログラム LSMLMW を用い, 性と処理の効果を 母数効果として分析した。 
表 2. 試験飼料の組成

\begin{tabular}{|c|c|c|c|c|c|c|}
\hline \multirow{2}{*}{ 配合割合（\%） } & \multicolumn{3}{|c|}{ 前 期 } & \multicolumn{3}{|c|}{ 後 期 } \\
\hline & 対照飼料 & $\mathrm{BS}$ & $\mathrm{BS}+\mathrm{AA}$ & 対照飼料 & BS & $\mathrm{BS}+\mathrm{AA}$ \\
\hline トウモロコシ & 69.28 & 55.70 & 55.61 & 76.79 & 42.80 & 42.61 \\
\hline 大豆粕 ～～ & 27.90 & 13.00 & 13.00 & 20.50 & - & - \\
\hline パン屑 & - & 18.00 & 18.00 & - & 30.00 & 30.00 \\
\hline トウフ粕 & - & 2.00 & 2.00 & - & 18.00 & 18.00 \\
\hline 脱脂米糠 & - & 4.00 & 4.00 & - & - & - \\
\hline 大麦荒糠 & - & 5.00 & 5.00 & - & 7.00 & 7.00 \\
\hline 植物性油脂 & 0.60 & - & - & 0.60 & - & - \\
\hline 第 2 リンカル & 0.70 & - & - & 0.50 & 0.55 & 0.55 \\
\hline 炭酸カルシゥム & 0.90 & 1.30 & 1.30 & 0.90 & 0.85 & 0.85 \\
\hline 塩酸 L-リジン & - & - & 0.40 & - & - & 0.34 \\
\hline L-トレオニン & - & - & 0.08 & - & - & 0.06 \\
\hline D, L-メチオニン & - & - & 0.08 & - & - & 0.08 \\
\hline $\mathrm{L}$-トリプトファン & - & - & 0.03 & - & - & 0.01 \\
\hline フィターゼ & - & 0.10 & 0.10 & - & 0.10 & 0.10 \\
\hline ビタミン・ミネラル & 0.62 & 0.30 & 0.40 & 0.71 & 0.70 & 0.40 \\
\hline $\mathrm{DE}, \mathrm{Mcal} / \mathrm{kg}$ & 3.37 & 3.39 & 3.37 & 3.44 & 3.43 & 3.43 \\
\hline $\mathrm{CP}, \%$ & 18.0 & 14.6 & 15.0 & 15.3 & 12.9 & 13.3 \\
\hline 粗脂肪，\% & 3.5 & 3.7 & 3.7 & 3.8 & 5.8 & 5.8 \\
\hline リジン，\% & 0.86 & 0.57 & 0.88 & 0.69 & 0.42 & 0.69 \\
\hline メチオニン＋シスチン，\% & 0.55 & 0.45 & 0.53 & 0.48 & 0.38 & 0.46 \\
\hline トレオニン, \% & 0.65 & 0.48 & 0.56 & 0.54 & 0.40 & 0.46 \\
\hline トリプトファン, \% & 0.19 & 0.14 & 0.17 & 0.15 & 0.13 & 0.14 \\
\hline
\end{tabular}

計算による成分値。

フィターゼは， 500 単位 $/ \mathrm{g}$ 力価（0.1\% 添加で飼料 $1 \mathrm{~kg}$ 当たり 500 単位）の屯のを使用。

$\mathrm{BS}$; パン屑を主体とする低タンパク質飼料。

$\mathrm{BS}+\mathrm{AA} ; \mathrm{BS}$ 飼料に, 要求量を満たすように単体アミノ酸を添加した飼料。

\section{結果および考察}

表 3 に, パン屑の給与が飼養成績と背脂肪厚と わき腹の脂肪厚（P2）に及ぼす影響について示し た。1 日増体量は, 対照区が $1.00 \mathrm{~kg} / \mathrm{d}$ であったの に対し，BS+AA 区が $0.98 \mathrm{~kg} / \mathrm{d}$, BS 区が 0.96 $\mathrm{kg} / \mathrm{d}$ と，パン屑給与によって低くなったが，個 体差によるばらつきが大きく有意な差ではなかっ た $(\mathrm{P}=0.68)$ 。また, 飼料摂取量と飼料要求率につ いては, アミノ酸を添加していない BS 区が低く なった。背脂肪厚については, 各区間に有意な差
は認められなかった（背脂肪肩; $\mathrm{P}=0.6620$, 背脂 肪背; $\mathrm{P}=0.5824$, 背脂肪腰 $; \mathrm{P}=0.0905) 。 \mathrm{P} 2$ は, 対照区の $2.1 \mathrm{~cm}$ に対して, BS+ AA 区が $2.2 \mathrm{~cm}$, $\mathrm{BS}$ 区が $2.4 \mathrm{~cm}$ と, BS区の方が $2 \mathrm{~mm}$ 程度厚くなっ たが，有意な差ではなかった（P=0.6667）。なお， 表には示さなかったが, 去勢の 1 日増体量は䧳の それより, 最小 2 乗平均值で $143 \mathrm{~g}$ 有意に大きく なった $(\mathrm{P}<0.01)$ 。また, 背脂肪厚は, 肩, 背, 腰 および $\mathrm{P} 2$ の最小二乗平均で，それぞれ $6 \mathrm{~mm}(\mathrm{P}<$ 0.01)， $5 \mathrm{~mm}(\mathrm{P}<0.01), 6 \mathrm{~mm}(\mathrm{P}<0.05)$ および $8 \mathrm{~mm}(\mathrm{P}<0.01)$ 去勢が此より有意に厚くなった。 
今回の実験において, BS 区で 1 日増体量が低 くなったのは, リジンなどのアミノ酸の含量が要 求量より低かったことが関係していると思われ る。また, 飼料に $5 \%$ パン屑を添加しても，1 日増 体量, 飼料摂取量, 飼料要求率は影響を受けない が8)，市販飼料の $50 \%$ をパンで代替すると， 1 日 増体量と飼料効率が悪くなる2)。岩本ら $(2005)^{2)}$ の報告では飼料摂取量が示されていないが，1日 増体量之飼料効率から計算すると, 飼料摂取量が 低下していたものと考えられる。本研究における パン屑の添加割合は，前期が 18\%，後期が 30\% である（表 2)。パン屑の容積は大きいので, 配合 量が 20〜30\%を超えてくると飼料の容積も大き くなり, 胃など消化管む物理的に圧迫されて飼料 摂取量が低下し, 結果的に増体にも影響が出るの かむしれない。一方で，BS区と同量のパン屑を 配合した BS＋AA 区の飼料摂取量が，対照区と 同等であることから，パン屑の容積以外の要因を 考慮する必要がある。肥育豚の飼料のリジン濃度 を $0.65 \%$ から $0.55 \%$ に下げると, 飼料摂取量む低 下するという報告がある ${ }^{9)}$ 。ブロイラーであ，飼 料中のリジン濃度を低くすると, 飼料摂取量が低 下する ${ }^{10)}$ 。これらの報告の結果を考慮すると, BS 区の飼料摂取量が低かったのは, リジンを含め て, いくつかのアミノ酸の飼料中に打ける濃度 が，対照区と BS+AA区よりあ低かったことが 関係しているのかもしれない。本研究では, 地域
未利用資源の有効利用を念頭におき, パン屑に加 えてトゥフ粕を飼料原量として活用した。BS 区 の $\mathrm{P} 2$ 脂肪が対照区よりも $2 \mathrm{~mm}$ 厚くなった理由 に, 粗脂肪含量が $10 \%$ を超えるトウフ粕を給与 したこと,リジンなどのアミノ酸含量が要求量よ り低かったことが考えられる。

図 1 に，パン屑の給与が胸最長筋における筋内 脂肪含量に及ぼす影響を示した。BS 区の胸最長 筋の筋内脂肪含量は対照区および BS + AA 区ょ りも高かったが $(\mathrm{P}=0.0515$ および $\mathrm{P}<0.05), \mathrm{BS}$ + AA 区と対照区の間に差は認められなかった。 また, 図には示さなかったが, 去勢の IMF は䧳の それより，最小 2 乗平均值で $1 \%$ 有意に高かった $(\mathrm{P}<0.05)$ 。

今回の実験においては，筋内脂肪含量を高める のに効果があると報告されている2) パン屑を給与 しているが，リジンを充足させた BS+AA区と対 照区の間に IMF の差は観察されなかった。また, BS 区と BS+AA 区の飼料には，パン屑に加えて トゥフ粕も配合しているので, 肥育後期飼料で粗 脂肪含量が高くなっており, 飼料摂取量から見積 あられる粗脂肪の摂取量屯, 対照区と比較して 1 日あたり 50〜 60 g 高くなる。しかし, BS+AA 区 の IMFには, 対照区の值と差がない。したがっ て, パン屑とトゥフ粕を給与することにより粗脂 肪の摂取量が高くなって屯, 不足しているアミ， 酸を添加して要求量を満たすように調整すれば,

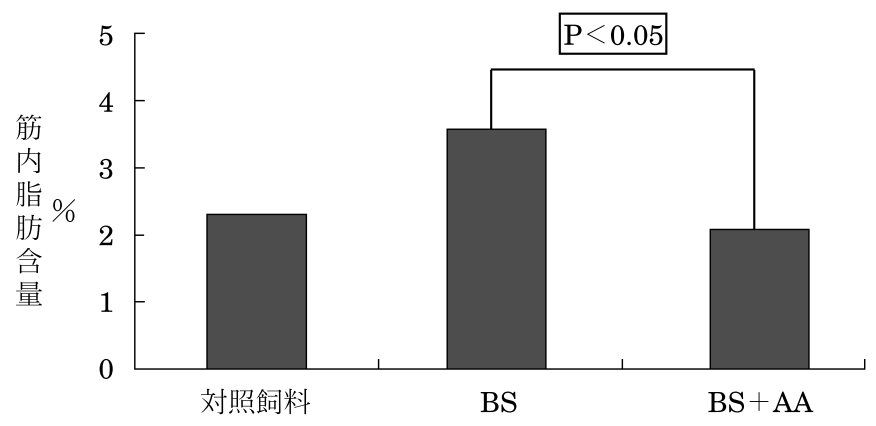

図 1. パン屑給与が胸最長筋における筋内脂肪含量に及ぼす影響 LCP 区と対照飼料区間 : $\mathrm{P}=0.0515$ 。

$\mathrm{BS}$; パン屑を主体とする低タンパク質飼料。

$\mathrm{BS}+\mathrm{AA} ; \mathrm{BS}$ 飼料に, 要求量を満たすように単体アミノ

酸を添加した飼料。 
IMF が高くならないことになる。KATSUMATA ら $(2005)^{6)}$ は，パン屑を活用していない，トウモロ コシと大豆粕を主体とした飼料でも，飼料中のリ ジンの充足率を要求量の $70 \%$ 程度にまで下げれ ば，他のアミノ酸は要求量を満たしていても，胸 最長筋の IMF が高くなることを観察している。 これらの結果は, パン屑を給与することによる胸 最長筋の IMF 増加は, パン屑のアミノ酸組成に 起因するリジンをはじめとするいくつかのアミノ 酸不足によるところが大きいという，2つめの仮 説を支持している。

また，70-110 kg 時に給与した BS 区の DE 含 量は, 日本飼養標準・豚 $(2005)^{5)}$ が推奨する 1 日 期待増体量 $850 \mathrm{~g}$ 時の DE 要求量, $3.30 \mathrm{Mcal} / \mathrm{kg}$ よりあわずか $3 \% \mathrm{DE}$ 含量が高いだけで, 特にエ ネルギー含量の高い飼料ではない。このことは, パン屑等食品リサイクル飼料を給与する場合む, 特にエネルギー含量が高くなくとも，BS 飼料は ロースの筋内脂肪含量を高くすることを示してい る。さらに, 本研究では, 3 つの試験飼料の DE 含 量が同じになるように設計した。表 3 に示すよう に, BS 区の飼料摂取量は約 $200 \mathrm{~g} / \mathrm{d}$, 対照区およ び BS+ AA 区の平均值よりあ低くなっている。 したがって, BS 区の DE 摂取量は, 他の 2 区より
も低かったと考えるのが妥当である。にもかかわ らず, BS 区の胸最長筋の IMF が他の 2 区よりあ 高かったことから，パン屑給与による IMF 増加 は, DE 摂取量の克進が主たる原因ではないと考 えられる。

市販配合飼料を $50 \%$ パンで代替すると, 背脂 肪内層のパルミチン酸含量が高まる一方で, リ ノール酸含量が低下する ${ }^{2)}$ 。この結果から, 給与 飼料中の脂質の影響が直接反映されるよりも, む しろ，パンの給与によって豚の脂肪酸合成が影響 を受け，体内での飽和脂肪酸の合成が盛んになっ たのではないかと岩本ら $(2005)^{2)}$ は考察してい る。さらに，低リジン飼料を給与した豚における 胸最長筋の中性脂質画分の脂肪酸組成を測定した ところ, リノール酸の割合が低くなり，オレイン 酸の割合が高くなることが観察されている レイン酸は豚が生合成する主要な脂肪酸なので, 豚の体内での脂肪酸の合成が活発になったこと を，この結果は示唆している。このように，パン の給与にせよ, 通常の飼料原量による IMF の増 加にせよ，体内で脂肪酸を生合成する活性が高ま り，結果的にIMF を増やすと考えられる。また，

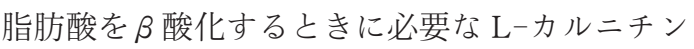
は,リジンとメチオニンを材料として合成され

表 3. パン屑給与が飼養成績と背脂肪厚に及ぼす影響

\begin{tabular}{|c|c|c|c|c|c|c|}
\hline & \multicolumn{2}{|c|}{ 対照飼料 } & \multicolumn{2}{|c|}{ BS } & \multicolumn{2}{|c|}{$\mathrm{BS}+\mathrm{AA}$} \\
\hline & $\mathrm{n}=8$ & S.E. & $\mathrm{n}=7$ & S.E. & $\mathrm{n}=7$ & S.E. \\
\hline 飼料摂取量（kg/d） & 3.21 & & 2.99 & & 3.25 & \\
\hline 1 日増体量（kg/d） & 1.00 & 0.03 & 0.96 & 0.04 & 0.98 & 0.04 \\
\hline 飼料要求率 & 3.21 & & 3.11 & & 3.32 & \\
\hline \multicolumn{7}{|l|}{ 背脂肪厚（cm） } \\
\hline 肩 & 3.8 & 0.1 & 4.0 & 0.1 & 3.8 & 0.1 \\
\hline 背 & 2.1 & 0.1 & 2.1 & 0.1 & 1.9 & 0.1 \\
\hline 腰 & 3.1 & 0.2 & 3.0 & 0.2 & 2.8 & 0.2 \\
\hline 3 点平均 & 3.0 & 0.1 & 3.1 & 0.1 & 2.8 & 0.1 \\
\hline P2 脂肪厚（cm） & 2.1 & 0.2 & 2.4 & 0.2 & 2.2 & 0.2 \\
\hline
\end{tabular}

飼料摂取量と飼料要求率は群の平均值，その他は最小 2 条平均值。

$\mathrm{BS}$; パン屑を主体とする低タンパク質飼料。

$\mathrm{BS}+\mathrm{AA} ; \mathrm{BS}$ 飼料に, 要求量を満たすように単体アミノ酸を添加した飼料。

S.E. ; 標準誤差 
る。BS 区では，これらのアミノ酸が不足してい たので，合成される L-カルニチンの量は抑えら れていたかもしれない。このことは, 脂肪酸の $\beta$ 酸化の抑制をま㸚き，結果的に IMF が増加した 一因となった可能性が考えられる。

以上のことから，パン屑を給与することによる 胸最長筋の IMF の増加は, いくつかのアミノ酸 が要求量を満たしていなかったことが，主たる原 因であったと結論出来る。このことは，卜ウモロ コシや小麦など，穀物原料と同等のアミノ酸組成 のものであれば，特にパンにこだわらなくても， 食品リサイクル飼料によって胸最長筋の IMFを 高くすることが可能なことを示している。一方 で, P2 脂肪が厚くなったように, 望ましくない脂 肪蓄積あ生じることがあるので, 食品リサイクル 飼料の給与量や，アミノ酸組成について，さらに 検討する必要む残されている。

食品リサイクル飼料を活用して豚肉を生産する ことは，資源循環型の社会構築に貢献するのは言 うまでもない。そして，そこから生産される豚肉 が高品質で消費者から喜ばれるものであれば，一 層重要な取り組みになると期待される。

\section{文献}

1）入江正和 : 豚肉質の評価法，日豚会誌， 39 , 221-254, 2002.

2）岩本英治・設楽 修・入江正和：パン添加 飼料給与がブタの増体量および肉質に及ぼ す影響，日畜会報， 76， 15-22，2005.
3）農業技術研究機構: 日本標準飼料成分表, 2001.

4）香川芳子監修: 五訂食品成分表 2002, 女子 栄養大学出版部，東京，2002.

5）農業・生物系特定産業技術研究機構：日本 飼養標準・豚，2005.

6) Katsumata, M., S. Kobayashi, M. MatsuMoto, E. Tsuneishi and Y. KaJI : Reduced intake of dietary lysine promotes accumulation of intramuscular fat in longissimus dorsi muscle of finishing gilts. Anim. Sci. J., 76, 237-244, 2005.

7) Harvey, W.R. : User's guide for LSMLMWmixed model least-squares and maximum likelihood computer program, Ohio State University, Ohio, Columbus, 1985.

8）鈴木啓一・清水ゆう子・門脇 宏 : 乾燥口 カメ茎とパン屑添加飼料給与が豚の産肉・ 肉質形質に及ぼす影響, 日豚会誌，39，6670, 2002.

9) Henry, Y., Y. Colleáux and B. SÈve : Effects of dietary level of lysine and of level and source of protein on feed intake, growth performance, and plasma amino acid pattern in the finishing pig. J. Anim. Sci., 70, 188-195, 1992.

10) Carew, L., J. McMurty and F. Alster: Effects of lysine deficiencies on plasma levels of thyroid hormones, insulin-like growth factors I and II, liver and body weights, and feed intake in growing chickens. Poultry Science, 84, 1045-1050, 2005 . 


\title{
Enhancement of Intramuscular Fat Content in Longissimus Dorsi Muscle of Finishing Pigs Fed a Low Lysine Diet Including Bread Crumbs
}

\author{
Seiji IeIri, Takeshi Sakimura, Makoto Isibasi*, Masaya Katsumata** and Yuji Kaj*** \\ Kumamoto Agricultural Research Center, Sakae 3801, Koshi-shi, Kumamoto, 861-1113, Japan \\ * Kumamoto Prefectural Government, Aso Extension Division, \\ Miyaji 2402, Aso-shi, Kumamoto, 869-2612, Japan \\ ** National Institute of Livestock and Grassland Science, \\ Ikenodai 2, Tsukuba, 305-0901, Japan \\ *** National Agricultural Research Center for Kyushu Okinawa Region, \\ Suya 2421, Koshi-shi, Kumamoto, 861-1192, Japan
}

Food co-products are currently recognized as important feed resources and thus a number of laboratories are focusing on research to improve quality of pork with appropriate utilization of food co-products. Although it is already well recognized that feeding breadcrumbs, a major food co-product, to finishing pigs enhances intramuscular fat (IMF) content in longissimus dorsi (1. dorsi) muscle, the underlying mechanisms is still unknown. As breadcrumbs mainly consist of wheat flour, their amino acid profile should be similar to that of wheat grain. Thus, diet for pigs including breadcrumbs may not meet requirement of certain essential amino acids. We hypothesize that the reason of enhancement in IMF content in 1. dorsi muscle due to breadcrumbs feeding is attributed to shortage of certain amino acids in the diets including breadcrumbs. From this background, we decided to conduct an investigation to elucidate whether amino acid profile of a diet including breadcrumbs plays a role in regulating IMF content in 1 . dorsi muscle in finishing pigs.

Diets prepared were as follows ; a control diet, a diet including breadcrumbs (BS diet), and a diet including breadcrumbs supplemented with amino acids (lysine, methionine, threonine, and tryptophan) to meet their requirements (BS+ AA diet). The control diet was mainly consisted of maize and soy bean meal. We used in total twenty four pure Landrace breeds pigs. Four barrows and four gilts were assigned to one of the three diets. The pigs were subjected to each diet when their live body weight reached to $40 \mathrm{~kg}$, and they were allowed free access to the diets and water until their body weight reached to $110 \mathrm{~kg}$. At the end of the trial, carcass traits were measured and IMF contents in 1. dorsi muscle were determined.

Although feeding the BS diet did not affect back fat depth, IMF contents in 1. dorsi of pigs fed on the BS diet were significantly higher than those of the other two groups (2.29\% for the control group, 1.98\% for the BS+AA group, and 3.52\% for the BS group, respectively ; $\mathrm{P}<0.05)$. Daily body weigh gain, feed intake, feed conversion efficiency, back fat depth, and fat depth at the P2 site of pigs fed on the BS + AA diet were not different from those of the pigs fed on the control diet. 
These results suggest that the well recognized effect of breadcrumbs feeding on IMF content in 1. dorsi muscle can be attributed to shortage of certain essential amino acids in diets including breadcrumbs.

Jpn. J. Swine Science, 44, $1:$ 8-16

Key words : Intramuscular fat, Finishing pigs, Low lysine diet, Bread crumbs 